\title{
Continuous programme renewal and critical citizenship: Key items for the South African higher education curriculum agenda
}

\begin{tabular}{|c|c|}
\hline \multicolumn{2}{|c|}{$\begin{array}{l}\text { Authors: } \\
\text { Eli Bitzer }{ }^{1} \text { (1) } \\
\text { Elmarie Costandius }{ }^{2}\end{array}$} \\
\hline \multicolumn{2}{|c|}{$\begin{array}{l}\text { Affiliations: } \\
{ }^{1} \text { Centre for Higher and Adult } \\
\text { Education, Stellenbosch } \\
\text { University, South Africa }\end{array}$} \\
\hline \multicolumn{2}{|c|}{$\begin{array}{l}{ }^{2} \text { Department of Visual } \\
\text { Design, Stellenbosch } \\
\text { University, South Africa }\end{array}$} \\
\hline \multicolumn{2}{|c|}{$\begin{array}{l}\text { Corresponding author: } \\
\text { Eli Bitzer, } \\
\text { emb2@sun.ac.za }\end{array}$} \\
\hline \multicolumn{2}{|c|}{$\begin{array}{l}\text { Dates: } \\
\text { Received: } 22 \text { Jan. } 2018 \\
\text { Accepted: } 23 \text { Apr. } 2018 \\
\text { Published: } 18 \text { June } 2018\end{array}$} \\
\hline \multicolumn{2}{|c|}{$\begin{array}{l}\text { How to cite this article: } \\
\text { Bitzer, E. \& Costandius, E., } \\
\text { 2018, 'Continuous } \\
\text { programme renewal and } \\
\text { critical citizenship: Key items } \\
\text { for the South African higher } \\
\text { education curriculum agenda', } \\
\text { Transformation in Higher } \\
\text { Education 3(0), a37. https:// } \\
\text { doi.org/10.4102/the.v3io.37 }\end{array}$} \\
\hline \multicolumn{2}{|c|}{$\begin{array}{l}\text { Copyright: } \\
\text { ( 2018. The Authors. } \\
\text { Licensee: AOSIS. This wo } \\
\text { is licensed under the } \\
\text { Creative Commons } \\
\text { Attribution License. }\end{array}$} \\
\hline \multicolumn{2}{|l|}{ Read online: } \\
\hline 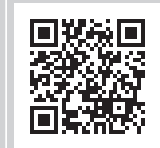 & $\begin{array}{l}\text { Scan this QR } \\
\text { code with your } \\
\text { smart phone or } \\
\text { mobile device } \\
\text { to read online. }\end{array}$ \\
\hline
\end{tabular}

In this article, we explore the term 'programme renewal' and then continue to point out why programme renewal bodes an essential topic for continuous inquiry and attention. We also highlight the importance of approaching programme renewal from a sound theoretical base and point to the important issue of promoting critical citizenship with students in learning programmes. We finally point to the links between programme renewal and critical citizenship through four sample cases.

\section{Introduction}

Jonathan Jansen, inspired by the work of Reid (2006), and Terwel and Walker (2004), writes as follows about the curriculum as an institution (Jansen, in Bitzer 2009):

\begin{abstract}
... the university curriculum is that idea expressed in multiple ways that include but go beyond the ways of teaching, learning and assessing within a particular institutional context. It encapsulates what most workers within that institutional setting understand to be the character, content and boundaries of knowledge that came with being in that place, the university. It extends to include the understanding by institution dwellers of the particular link between knowledge and authority, about who possesses knowledge to act on and against others, and who are positioned simply as the recipients of authoritative knowledge. (pp. 126-127)
\end{abstract}

Issues of power, knowledge, access, inclusion and authority are thus foregrounded as institutional curriculum questions of major importance. Since Jansen's 2009 observation, many of these issues emerged prominently, and even dramatically, across the South African higher education landscape. These issues include student protests under the '\#Feesmustfall' banner, demands for 'decolonised' university curricula, the appointment of the Heher Commission of Inquiry into university funding, the closing of some programmes in Law education and the replacement of at least one minister of Higher Education and Training. Much of the backwash of these developments is still experienced and visible in several, if not all, South African universities (Behari-Leak, Ramugondo \& Kathard 2016; Butler-Adam 2016).

Against the troublesome and turbulent South African higher education background, we (the authors) are convinced that multiple reasons exist why universities must engage in innovative and continuous programme renewal, including:

- Programmatic responsiveness to changing internal and external higher education and professional contexts - in particular programme responsiveness to funding trends, policy changes, student demographics, increasingly diverse student bodies, the increasingly important role of information and communication technologies as well as to new knowledge markets.

- Maintenance of programmatic sustainability and programme relevance to enhance job opportunities for graduates.

- Planning and renewal of programmes in systematic, integrated and pro-active ways rather than in ways that are haphazard, fragmented and reactive.

- Identification of educational priorities such as promoting graduate attributes, threshold learning outcomes, efficient throughput and the quality of the overall student learning experience.

Given the importance of programme renewal, we hold the view that continuous programme renewal needs to be considered as an essential item on the higher education curriculum agenda in South Africa and elsewhere. 
In the rest of this article, we explore the term 'programme renewal' and then continue to point out why programme renewal bodes an essential topic for continuous inquiry and attention. We also highlight the importance of approaching programme renewal from a sound theoretical base and point to the important issue of promoting critical citizenship with students in learning programmes. We finally point to the links between programme renewal, critical citizenship and four sample cases.

\section{Programme renewal}

'Programme renewal' refers to the constant review, change and implementation of undergraduate and postgraduate university programmes as a response to internal and external educational, knowledge, economic and social needs (Desha \& Hargroves 2014; Oliver 2013; Waters, Rochester \& MacMillan 2012). However, programme responsiveness, as institutional or programmatic action, cannot and should not forfeit the unique institutional missions of universities. Constant and continuous programme renewal should rather, within the context of institutional missions and the university as an institution, strive to meet the needs of increasingly technologically oriented economies to address the charge for relevant research, and to produce properly qualified graduates equipped to develop, keep on learning and participate in rapidly changing and competitive global environments (Bitzer \& Botha 2011; Oliver 2013).

Nationally, as South African universities are attempting to meet pressing needs within the African and global higher education contexts, programme responsiveness has become a central policy issue (Ogude, Nel \& Oosthuizen n.d.). Yet, while efforts to renew and restructure university programmes are increasingly responsive, programmatic outcomes often appear incompatible. For instance, some outcomes may respond to immediate market needs, but, at the same time, do not produce the knowledge and skills required for new knowledge economies (also see Stumpf 2005). This raises the following questions: How can higher education programmes respond to new knowledge demands? How can such responsiveness be operationalised? How may strategic and continuous programme renewal become an important and regular university feature?

\section{Continuous programme renewal}

The renewal of university programmes implies several theoretical and practical dimensions. These dimensions include the basis of the renewal, the nature and extent of the renewal, how the demands of external and internal requirements are met (Fox 2009), how programmes align with emerging policies, and how responsive are programmes to contextual changes (Desha \& Hargroves 2014). Programme renewal also relates to changes in disciplines and knowledge regimes (Waters et al. 2012), the optimal use of resources and the continuous improvement of programmatic quality (Oliver 2013).
Within the African context, calls for the decolonisation of universities, which implies 'decolonised' university curricula, became prominent in South Africa during the 'Rhodes must fall' campaign. It is in this context that Mbembe (2015) argues, for instance, that many academic and professional university degree programmes reflect obsolete forms of knowledge and irrelevant pedagogies. He offers a particularly powerful critique of the dominant Eurocentric approach to curriculummaking and programme development, including arguments against the hegemony of knowledge production within a Western canon. He also proposes the reshaping of student learning to increasingly favour the mastering of crafts, and for students to take more responsibility and ownership for curriculum transformation.

Partly as a response to student and scholarly critique on favouring Westernised canons of knowledge and pedagogies, one South African university (University A 2017) produced an extensive investigative report on 'decolonising' the curriculum. Its main recommendations include that:

- the institution acknowledges a discriminatory past and creates spaces for reconciliation and restitution;

- the institution includes decolonisation as a core aspect of its systemic transformation with related themes such as place, programmes and people;

- engagement about curricula should happen within spaces that are sympathetic to the needs of marginalised groups and not be dictated by institutional management;

- decolonisation terminology should be commonly explained and understood so that debates on decolonisation can take place across the institution;

- the institution should provide resources and support for staff members who engage in decolonisation initiatives for teaching, learning and curriculum renewal which includes creating opportunities to bridge the gap between formal and cocurricular spaces;

- the institution should expand spaces for engagement by open discussions of what social justice may mean in relation to decolonisation.

Earlier, another programme renewal inquiry at the same university focused on the issue of critical citizenship (Costandius \& Bitzer 2015). This investigation adopted a critical pedagogical stance whereby the links between university curricula and broader societal change were pointed out in terms of how a public university, through its academic and professional programmes, is increasingly expected to make relevant contributions for the public good. The study also indicated how important social issues such as equity, equal opportunities, social cohesion and relational human capital can be promoted by programme renewal. We shall return to some of these aspects later in this article.

The involvement of students, the recipients of learning, in programme planning and implementation is promoted - also in non-African contexts. For instance, a total of 103 universities in the US and 17 from outside the US responded to a survey on the impact of university curricula. The participating institutions 
indicated overwhelmingly that they did not consider students as 'objects of teaching' or being part of programme experimentation. They rather aim to actively involve them in campus conversations and participation in programmatic matters (Werder \& Otis 2010).

In Australia, Curtin University (2011) launched a major initiative to ensure that the institution's degree programmes are internationally competitive and sustainable to benefit their graduates and society at large. Programme sustainability focused mainly on efficiencies gained through deactivating and restructuring degree programmes, while the quest for excellence supported the ideal of constructively aligning programmatic learning outcomes, the assessment of student learning and promoting clearly identified graduate attributes (Biggs \& Tang 2007). The underlying premise in the Curtin case was that the achievement of general and specific graduate attributes would lead to enhanced employability (Yorke 2006), while the initiative was launched against the background of an increasingly competitive higher education environment where programme excellence is one of the major keys to institutional survival and prosperity.

Another Australian university, the University of Adelaide (2013), also adopted a strategic approach to underpin its curriculum renewal process and to promote inclusivity, collaboration and anticipation. Key aspects of their programme renewal and mapping process included questions such as:

- What do students need to do to achieve expected levels of knowledge, skills and applications (student learning activities)?

- What do students need to do to demonstrate that they have achieved programme and course learning outcomes (assessment of learning)?

In the Adelaide case, programme renewal revolved around two main issues, namely the purpose of programme renewal, and how the 'fitness for purpose' was going to be determined. The reigning argument was that 'fit for purpose' programmes could not be designed and renewed if the exact purpose of the programme is unclear.

Even within these limited number of examples, the need for and importance of continuous programme renewal are obvious for a number of reasons:

- Firstly, universities that do not respond to internal and external needs and demands might soon be 'out of business' in highly competitive educational environments.

- Secondly, graduates need to be equipped as best as possible for their respective professions for employment opportunities, for research careers and for making contributions as entrepreneurs. This can rarely happen at institutions with no inclination towards constant and continuous programme renewal.

- Thirdly, programmes offered by public universities need to prepare students to make societal contributions and to become worthy and critical citizens. This can happen if both academic and administrative staff have a sense of what such citizenship means for programme planning and offerings.

- Fourthly, university programme inquirers and planners have to be sensitive to bias towards particular philosophical, political and other underlying preferencesespecially in polarised environments such as in South African higher education and in broader societal contexts.

Before we address critical citizenship as a particularly important programme renewal issue, the reader might be briefly reminded of the theoretical underpinnings of programme renewal. This reminder does not aim to be comprehensive, but rather to suggest that programme renewal and its accompanying strategies are, and should be, based on sound curriculum theory.

\section{A brief theoretical perspective on programme renewal}

Geyser (2004:151) refers to four core 'principles' that need to be aligned when reviewing higher education programmes. These are: (1) a thorough analysis of those strategic factors that impact on the programme under review; (2) a critical analysis of the programme outcomes; (3) a serious (re) consideration of the teaching and learning that take place within the programme and (4) a review of the reigning assessment practices. These 'principles' form part of a wide range of reported curriculum renewal options and models (Du Toit 2011; University College Dublin 2010).

In addition, programme review is comfortably underpinned by a constructivist view of reality (Muijs \& Reynolds 2005), where new ideas and knowledge are constructed based on the experience of, involvement in and a shared understanding of programme renewal rather than being perceived from the reviewers' senses or 'gut-feel' (Muijs \& Reynolds 2005:61). This stance supports the views of curriculum theorists, such as John Dewey and Lawrence Stenhouse, who saw curriculum and programme renewal as processes guided by the identified learning needs of students (Du Toit \& Du Toit 2004; Pinar 2010). Other renewal options, namely programme renewal based on canons of knowledge, subjects, disciplines or the solution of problems are all underpinned by prominent renewal theories involving epistemological or pragmatic perspectives (see Oliver et al. 2010; University of British Columbia 2016).

Biggs and Tang (2007) added much value to programme renewal theory with their research on 'constructive alignment', fusing two important renewal driving principles: constructivism, and the alignment between the intended outcomes, student learning activities and the assessment of such activities within a programme. Stefani (2009:48) views the idea of 'constructive alignment' as central to curriculum design and renewal, as it provides for a scholarly dialogue on programme issues, including achievable outcomes, programme standards, module structures, learning activities, learning assessment and programme evaluation. 


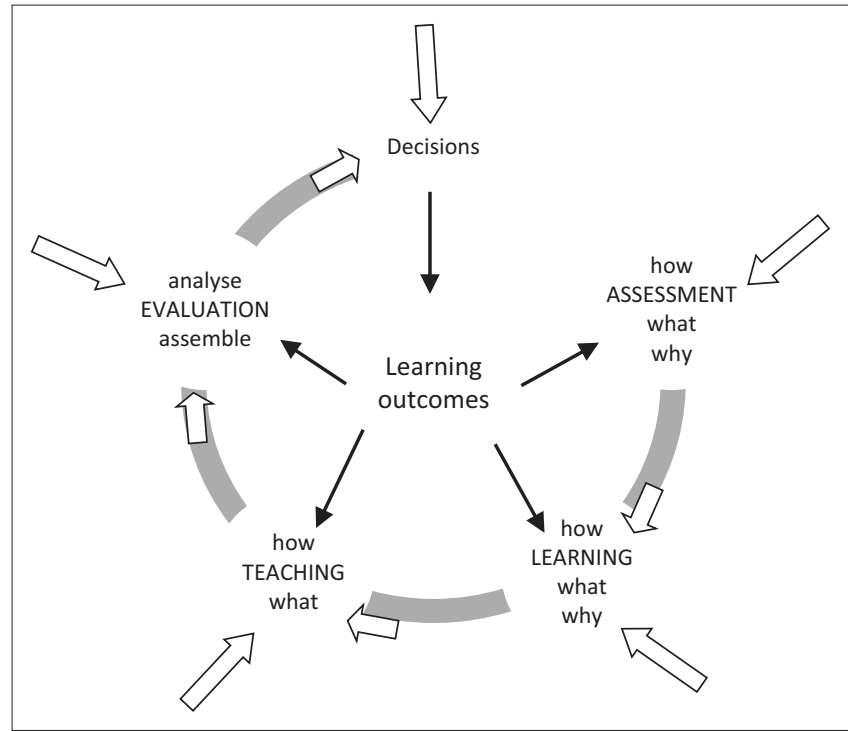

Source: Adapted from Stefani (2009).

FIGURE 1: A typical process model of programme renewal.

Figure 1 depicts the format of a typical programme renewal process (also see Stefani 2009:53) where explicit learning outcomes form the centre of the renewal model. Learning activities, learning content, specification of the learning context(s) as well as the standards to be attained importantly, inform the intended learning outcomes (Biggs \& Tang 2007).

The arrows pointing inwards signify the inputs from various sources and/or stakeholders such as scholarly peers, the institution, the community, employers, government and professional bodies. The questions 'how? what? why?' force those involved in programme renewal to question and reflect on their educational practices. The arrows pointing clockwise and those pointing outwards from the learning outcomes indicate the process of alignment. An evaluation of the total programme renewal and implementation process informs future programmatic decisions to improve and/or adapt the programme's intended learning outcomes.

An issue strongly advocated in programme renewal is for higher education programmes to aim at educating students with critical attributes regarding their own role in teaching and learning as well as their role within a broader social reality, once they have completed their qualifications. This highlights the importance of programme renewal that accommodates elements of critical citizenship which we address next.

\section{Programme renewal and critical citizenship}

Recently, the acclaimed higher education researcher, Ron Barnett, stated that to him there is no matter more important for universities than the programmes they offer; thus, there is no larger matter for inquiry than those very programmes (Barnett, in Bitzer \& Botha 2011:15). Yet, the matter of programme inquiry and renewal does not attract the attention it deserves among those who conduct research into higher education, whether through theorising or via empirical research.

The ways in which university programmes are developing, in both national and global environments, call for important inquiry, particularly in young democracies such as South Africa. However, considerable challenges, such as organisational, disciplinary, theoretical and methodological challenges, may emerge during such an inquiry. Moreover, it presents important citizenship challenges that one might consider as ideological. For instance, what kinds of values do we wish our degree programmes to represent? What kind of culture in the wider world do universities help to promote through their programmes? What kind of world (or country, as in South Africa) do we have in mind as a horizon for our higher education programmes? And finally, what would be the nature of development that higher education institutions want to engender among their students?

Many university programmes have the potential to promote critical citizenship. But what do such attempts entail? Promoting critical citizenship in learning programmes involves introducing a common set of shared values which include tolerance, diversity, human rights and democracy in student learning (after Johnson \& Morris 2010:77-78). As an educational programme and pedagogy, critical citizenship encourages critical reflection on the past and the imagining of a possible future shaped by social justice in preparation of living together in harmony in diverse societies. Critical citizenship education is therefore specifically aimed at the transformation of thinking on a personal level towards a wider public good.

Critical citizenship, as a concept and a practice in higher education programmes, links particularly well to critical pedagogy. The term 'critical pedagogy' refers to a set of education principles and practices closely related to critical thinking a main concern for the Frankfurt School of thought where the 'practice' of teaching and promoting critical thinking in modern times emerged from. The term also resonates strongly with Freire's pedagogy of the oppressed (1993). Critical pedagogy encourages academics, as educators, to develop context-specific programmes and strategies where both staff and students use dialogue to encourage a critical consciousness that involves citizenship issues (Johnson \& Morris 2010). As programme renewal agent, critical citizenship can serve to promote transformation, to imagine a possible future and to affect broad societal change.

Furthermore, a critical citizenship perspective in programme renewal may assist in addressing both local and global calls for social transformation which is seen by Makgoba (1997:22) as '... a noticeable change in form or character'. He argues that transformation is not reform, but rather 'blueprint change'. Similarly, Fourie (1999:277) refers to Harvey and Green (1993:24), who suggest that '... [t]ransformation is not 
restricted to apparent or physical transformation but also includes cognitive transcendence'. To return to Jonathan Jansen's observation in the opening section of this article: Promoting critical citizenship in South African university programmes works against the perpetuation of existing perceptions and attitudes that stem from a colonial and apartheid past towards a shared future.

As university graduates can contribute greatly to broader societal change (Costandius \& Bitzer 2015; Smith-Tolken 2011), it seems imperative that university learning programmes are informed by critical citizenship perspectives. Internationally, there are constant attempts to relate university programmes closer to societal issues and problems (Desha \& Hargroves 2014; Giroux 2014), and public universities are expected to make relevant contributions for the public good (Leibowitz 2012). International higher education research agendas for programme inquiry are thus increasingly addressing important social issues such as equity, social cohesion and relational human capital.

\section{Issues related to critical citizenship in programme renewal}

Botha (2009) highlights some dimensions of the debate around university programmes by referring to the internationalisation of universities as compared to their localisation. In South Africa, localisation often points to being situated on and being part of the African continent. Many South African universities are therefore grappling with identifying the 'most appropriate' programmatic balance or focus, especially against the background of local skills shortages, on the one hand, and pressures to compete internationally, on the other. Should a global citizenship be favoured above a local citizenship, or how can a balance be struck?

In his most recent book on the effects of neoliberalism in higher education, Henry Giroux (2014) suggests that many academics are either unwilling to address the current attacks on the university programmatic curriculum or are disturbed over how the language of specialisation and professionalisation has cut them off - not only from connecting their work to larger civic issues and social problems, but also from developing any meaningful relationships with a larger democratic society. A critical citizenship approach in programme renewal thus requires a deep involvement by academics as lecturers and researchers, considering the political aspects and power influences that are always present in programme renewal.

Moreover, with their statement '.. the political is always pedagogical', Helfenbein and Shudak (2009:8) argue that lecturers have a duty not only to teach students to care, but also to teach them what to care about; in other words, to teach how to '... engage in the battle [...] of ideas'. Thus, lecturers must accept the 'burden' of '... intellectual and moral responsibility concerning the instruction in and of democracy' (Helfenbein \& Shudak 2009:8). Michael Apple (2010:658) and Henry Giroux (2014) argue that education at any level is not a neutral, technical activity. Rather, as an act of influence, it must be seen as an ethical and political act. Often these informal aims are not written into the formal degree programme curriculum. Therefore, reflecting on the content of one's teaching is crucial, asking whether spaces are created to develop critical thinking. An inclusive critical citizenship programme or the incorporation of critical citizenship education into a programme curriculum can potentially influence students and community members.

Programmes that promote or include critical citizenship should therefore incorporate learning spaces (Bozalek 2004:71) where lecturers and students could come to terms with the past, including both those being discriminated against and the discriminators in ways that Jansen (2009a:264) refers to as '... disrupting settled ways of knowing'. The learning, referred to by Jansen, implies spaces where open conversations can take place in safe and non-threatening environments.

\section{Examples of promoting critical citizenship in programme renewal}

Community engagement constitutes only one, however important, example of how critical citizenship education can transform programme curricula (Smith-Tolken 2011). The aim of introducing community engagement in university programmes is to narrow the gap between universities and their communities (Costandius \& Rosochacki 2012), and to establish a new set of values that is sensitive to citizenship and citizenship education through various platforms of learning. In addition, community engagement suggests explorative work in higher education curricula that promotes reciprocal learning between students, lecturers, and civic and other communities. All such learning points to programmes of learning that enable students and lecturers to gain new, but sometimes discomforting, experiences and perspectives. It also suggests programme curricula that promote nonconforming institutional and psychological learning spaces which consider past and current political and societal challenges.

We want to highlight at least four examples of how critical citizenship can promote thinking and action at the programme renewal. These examples were all experienced first-hand by one of or both the authors as either programme renewal researchers or consultants at University A.

\section{Example 1}

As a programme renewal exercise, the Department of Visual Arts recently included a critical citizenship module in their BA in Visual Communication Design programme. The module aimed to sensitise students towards upholding the University's vision, values and commitment to critical citizenship and to demonstrate such sensitivities in their leaning with and within communities outside of the University (see also Costandius \& Bitzer 2015:76-105). The module included a number of well-planned projects and activities that involved art students and school learners from a neighbouring predominantly black township. The students, 
with their lecturers, were learning the importance of taking the emotional aspects of critical citizenship education seriously, moving beyond the emotional to rational actions and learning by 'opening up' to alternative views as well as questioning of own assumptions and values.

New educational strategies emerged strongly from this exercise, including dialogue, community interaction, reflection and new media for expression of thoughts and ideas. It further became evident that more and longer sessions for dialogue between students and lecturers were needed to allow students to voice their experiences and concerns within both safe and disruptive learning spaces (see Killen 2006) to discover new realisations about themselves, their relations to others and their relation to society. The programme renewal in this case proved to be highly effective in promoting experiential, relational and non-hierarchical learning activities among students and course staff.

\section{Example 2}

Early in 2017, the programme accreditation report for the LLB programme at University A was released (Council on Higher Education [CHE] 2017). Although the programme was found to be in good order and of good quality, the CHE commented as follows on the issue of promoting social justice (CHE 2017):

In the opinion of the panel, though, the LLB curriculum can and should do more to create an awareness among its students of the important role law plays in responding (or failing to respond) to social injustice. Apart from the final-year elective module, Practical Legal Training, in which students participate in the Law Clinic (around 30-40 students register for this module per year), students are not exposed in the curriculum to law-in-action studies. There is no Street Law module, for example, nor do any of the final-year electives provide for a public interest law module. The panel suggests that the Faculty should consider, in the revised curriculum they are contemplating, that provision be made for one or more modules where students are required to engage with law-in-action from a public interest perspective, in order to instil in them an appreciation of how law can and should respond to social injustice that permeates South African society. (p. 3)

As part of a complete overhaul of the LLB programme in 2017, a programme renewal working group in the Faculty of Law proposed a new programme model where critical skills and attributes were to be integrated into all Law subjects from the onset of the programme. In particular, social justice issues and student support were suggested to be seamlessly integrated into the first year of study, followed by more 'specialised' learning in the following years. As the LLB programme renewal process is still being debated and refined, no firm implementation results are currently available. However, programme responsiveness to social justice and critical citizenship issues were evident from the exercise in 2017 and will continue into 2018.

\section{Example 3}

The MBChB programme at University A was originally introduced in 1956. It evolved from an entirely 'traditional' medical curriculum to the introduction of an organ systembased curriculum with separate pre-clinical and clinical organ system modules in 1999. The current curriculum, which was introduced in 2008, consists of single, integrated organ system modules. An inter-professional phase was also incorporated in the first semester of the first year. The MBChB programme was accredited by the Health Professions Council of South Africa (HPCSA) in 2011 and 2017, respectively, for a maximum period of 5 years. Research by the Centre for Health Professions Education (CHPE) in the Faculty of Medical and Health Sciences also showed that different cohorts of graduates were well prepared for their internships.

Yet, in spite of programmatic successes, several international, national and local developments urged the programme leaders to consider programme renewal. For example, internationally, a seminal Lancet Report (Frenk et al. 2010) on the transformation of health professions education was one of the main catalysts for global curriculum reform initiatives within health professions. The report indicated that professional education did not keep pace with the health needs of populations and revealed a mismatch of graduate competencies to patient and/or population health needs, inadequate teamwork skills, a narrow technical focus (lacking holistic training encompassing all graduate attributes), episodic patient encounters rather than continuous care, predominant hospital orientation at the expense of primary health care and inadequate leadership skills for improving health systems' performance.

At the national level, the Medical and Dental Professions Board (MDB) accepted the Lancet recommendations and developed a national core competency framework (Medical and Dental Professions Board of the HPCSA 2014), using the 2005 CanMEDS competency framework (Frank 2005) as a guideline and incorporating social accountability as a measuring tool. Similarly, at the local (university) level, a contextualised graduate attributes and/or core competency framework was developed to move towards transformative student learning, to facilitate the introduction of the doctor as change agent in communities and to promote communication skills in isiXhosa.

Given all of the above, major curricular reform was inevitable and started with intensity in 2017. The proposed structure of the envisaged new MBChB curriculum initially used the metaphor of a double-stranded DNA helix. The one strand represented the theoretical and clinical components of the curriculum, while the other represented the graduate attributes. Graduate attributes were thus interlinked with curriculum content and clinical exposure, building spirally on threshold concepts along a developmental continuum. The base pairs of the DNA strands represented a continued, longitudinal focus on the self, the patient, the community and the health care system.

The conceptualisation of modules of the new MBChB curriculum is still evolving and will be further developed by expanded module teams during 2018. For instance, the first 
study semester of the new programme will entail a module for all students, titled 'Being and Becoming' and will focus on the transition from school to university, addressing questions such as: How do we help students to become more self-directed in their learning? How do we help them to understand the healthcare and social systems in which they will become professionals? How do we help them to understand their own identity development and to develop graduate attributes such as becoming critical citizens?

\section{Example 4}

In recent programme renewal projects across a number of disciplines and fields of study at University A, the re-orientation and development of programme staff proved to be crucial for encouraging and incorporating critical citizenship into programmes of learning. Critical citizenship education, when adopted by departments or faculties, encourages further research into different strategies, approaches and applications to collaboratively work towards personal and social transformation. In those programmes, which were effectively making progress with critical citizenship education, the academic staff were prepared to be involved in curriculum change and evolution. It became clear that only through the actual practical implementation of critical citizenship education, academic staff were able to learn and improve their efforts towards promoting this important programme element, as each programmatic setting clearly has unique characteristics. Thus, implementing and experiencing a course or a module in its specific programmatic setting or context is necessary before any limiting or promotional aspects of critical citizenship can be identified.

Moreover, it became evident that to educate for critical citizenship, academic staff needed a combination of subject knowledge (e.g. in art and design, law, health sciences, chemistry, theology, and sociology), experience in working with communities external to the University, and an interest in and awareness of critical citizenship education. As this is not a common combination of skills, some of these skills need to be learned. Also, research into the effectiveness of incorporating critical citizenship in programmes should preferably be conducted by representatives from a range of different backgrounds so that it can be investigated and promoted from various vantage points.

These four examples, taken from different programmatic contexts at one university, serve to illustrate how continuous and innovative programme renewal can purposefully and actively promote elements of critical citizenship.

\section{Discussion}

When one considers the need for as well as the scope and complexity of programme renewal, a few salient points emerge.

Firstly, as confirmed by many authors (Apple 2010; Du Toit 2011; Giroux 2014; Jansen 2009a; Reid 2006; Terwel \& Walker 2004), curriculum issues such as power, inclusion, exclusion, justice, citizenship, authority, relevance and curriculum intent cannot be separated from programme renewal. Thus, it seems imperative that programme renewal staff and curriculum researchers keep these issues on their agenda. However, it is to be expected that current South African higher education complexities, such as demands for student access into universities, student funding, university financing, decolonisation of curricula and educational quality (BehariLeak et al. 2016; Butler-Adam 2016), will enjoy priority, pushing issues like programme renewal and critical citizenship education to the bottom of the agenda. Yet, programme renewal and critical citizenship education may effectively address some of these more 'important and urgent' issues quite effectively.

Secondly, while many good reasons exist for seriously engaging in programme renewal, often involving radical changes in international, national, institutional, professional and other contexts (Costandius \& Bitzer 2015; Desha \& Hargroves 2014; Jansen 2009b), it is vital that programme renewal and critical citizenship education should not be haphazard and episodic attempts towards their promotion at universities. Academic staff preparation for and involvement in programme renewal should be an institutional imperative, as programmes and graduates are the main 'currencies' of universities. Much attention to such currencies, which requires constant, planned and regular phases of renewal and evaluation, is thus needed. The same goes for critical citizenship education, as only involvement and experience can contribute to real and deep transformation of learning. Teacher preparation programmes that include courses, workshops and field experiences might be needed to develop teachers' professional competencies and the confidence to educate for critical citizenship (also see Ladson-Billings 1999).

Thirdly, programme renewal expertise and support are essential and thus it is important to understand and apply the theoretical underpinnings related to programme renewal (Du Toit 2011; Frenk et al. 2010; Geyser 2004; Helfenbein \& Shudak 2009). In the case of University A, for instance, an internationally acclaimed programme renewal researcher and facilitator was contracted not only to run a series of renewal workshops with programme staff, but also to develop a sound programme renewal model for institutional and programmatic use. Although all the programmes nominated for renewal did not follow the same 'recipe', the same principles and broad guidelines were utilised to promote and execute the programme renewal projects. Certain principles also need to be applied and guidelines followed for promoting critical citizenship in learning programmes. Some programmes will adopt and adapt modules and courses quite easily to facilitate critical citizenship (e.g. arts, humanities, sociology, theology, health, education and others), while other programmes might find the challenge more demanding (e.g. engineering, military science, physics, accounting and others).

Lastly, while we do not assert that promoting critical citizenship education in programme renewal should be the main driver for change, we do claim that it is currently more 
important than ever before for universities to cultivate graduates that are sensitive towards and contribute to societal change and harmony. In a diverse and divided country such as South Africa, this is of the utmost importance. Graduates and professionals whose sole concern is their personal interest, without considering the wider national and community interest in some form or the other, do not contribute to those values held dearly by international, national and local communities. In his now acclaimed book Homo Deus - A Brief History of Tomorrow, Harari (2015:376-377) warns against a future world dominated by technology, controlled by an elite few who know and own important algorithms and who do not have any feel for human inequality, suffering and injustice, causing and growing de-humanised societies and oppressive orders.

\section{Conclusion}

Ideally, a critical citizenship perspective in continuous programme renewal must include a clear definition of the concept of critical citizenship, substantial links to critical thinking and critical pedagogy, and a guiding framework for critical citizenship education. The challenge of 'critically engaged' programme curricula is to address institutional autonomy and public accountability in an increasingly differentiated South African higher education system.

Creating a safe space for engagement founded on mutual trust and dialogue might be needed, reinforced by collaborative knowledge production where students need to take control of their own learning in the political, social and cultural contexts where learning takes place.

Despite numerous, complex and ever-shifting forces striving for power in constructing such curricula, engaging curricula via critical citizenship education requires an increasingly participative and inclusive approach.

\section{Acknowledgements Competing interests}

The authors declare that they have no financial or personal relationships which may have inappropriately influenced them in writing this article.

\section{Authors' contribution}

Both authors equally contributed to the research and writing of this article.

\section{References}

Apple, M.W., 2010, 'Political research', in C. Kridel (ed.), Encyclopedia of curriculum studies, pp. 658-661, Sage, Los Angeles, CA.

Behari-Leak, K., Ramugondo, E. \& Kathard, H., 2016, 'Students in South Africa feel unheard. Here's one way to listen', The Conversation, 11 October, p. 1.

Biggs, J. \& Tang, C., 2007, Teaching for quality learning at university: What the student does, 3rd edn., Open University Press, Berkshire.

Bitzer, E. \& Botha, N. (eds.), 2011, Curriculum inquiry in South African higher education Some scholarly affirmations and challenges, Sun Press, Stellenbosch.

Bitzer, E.M. (ed.), 2009, Higher education in South Africa, A scholarly look behind the scenes, Sun Media, Stellenbosch.
Botha, N., 2009, 'Intercultural space in higher education curricula', in E.M. Bitzer \& N. Botha (eds.), Curriculum inquiry in South African higher education: Some scholarly affirmations and challenges, pp. 159-182, Sun Press, Stellenbosch.

Bozalek, V., 2004, Recognition, resources, responsibilities: Using students' stories of family to renew the South African social work curriculum, viewed 05 February 2012, http://igitur-archive.library.uu.nl/ dissertations/2004-1203-094505/full =Pdf

Butler-Adam, J., 2016, 'What really matters for students in South African higher education?', South African Journal of Science 112(3/4), Art. \#a0151, 2 pages. https://doi.org/10.17159.sajs.2016/a0151

Costandius, E. \& Bitzer, E.M., 2015, Engaging higher education curricula. A critical citizenship education perspective, Sun Media, Stellenbosch.

Costandius, E. \& Rosochacki, S., 2012, See Kayamandi - See yourself, Sun Press, Stellenbosch.

Council on Higher Education (Higher Education Quality Committee), 2017, The National Review of Bachelor of Law (LLB) programmes, First Draft Report, Pretoria.

Curtin University, 2011, Scorecard report on teaching and learning, Curtin University, Perth, Western Australia.

Desha, C. \& Hargroves, K., 2014, Higher education and sustainable development: A model for curriculum renewal, Routledge, London.

Du Toit, G., 2011, 'Curriculum types and models: A theoretical inquiry', in E.M. Bitzer \& N. Botha (eds.), Curriculum inquiry in South African higher education: Some scholarly affirmations and challenges, pp. 59-79, Sun Media, Stellenbosch.

Du Toit, G.F. \& Du Toit, E.R., 2004, 'Understanding outcomes-based education (OBE)', in J.G. Maree \& W.J. Frazer (eds.), Outcomes-based assessment, pp. 1-27, Heinemann, Sandown.

Fourie, M., 1999, 'Institutional transformation at South African universities: Implications for academic staff', Higher Education 38(3), 275-290. https://doi.org/ 10.1023/A:1003768229291

Fox, J.D., 2009, 'Moderating top-down policy impact and supporting EAP curricular renewal: Exploring the potential of diagnostic assessment', Journal of English for Academic Purposes 8(1), 26-42. https://doi.org/10.1016/j.jeap.2008.12.004

Frank, J.R. (ed.), 2005, The CanMEDS 2005 physician competency framework. Better standards. Better physicians. Better care, The Royal College of Physicians and Surgeons of Canada, Ottawa, Canada.

Freire, P., 1993, Pedagogy of the oppressed, Continuum, New York.

Frenk, J., Chen, L., Bhutta, Z.A., Cohen, J., Crisp, N., Evans, T. et al., 2010, 'Health professionals for a new century: Transforming education to strengthen health systems in an interdependent world', The Lancet 376(9756), 1923-1958. https:// doi.org/10.1016/S0140-6736(10)61854-5

Geyser, H., 2004, 'Programme development and a curriculum design perspective', in S. Gravett \& H. Geyser (eds.), Teaching and learning in higher education, pp. 139-156, Van Schaik, Pretoria.

Giroux, H.A., 2014, Neoliberalism's war on higher education, Haymarket Books, Chicago, IL.

Harari, Y.N., 2015, Homo Deus. A brief history of tomorrow, Penguin Books, London.

Harvey, L. \& Green, D., 1993, 'Defining quality', Assessment \& Evaluation in Higher Education 18(1), 9-34. https://doi.org/10.1080/0260293930180102

Helfenbein, R.J. \& Shudak, N.J., 2009, 'Reconstructing/reimagining democratic education: From context to theory to practice', Educational Studies 45, 5-23. https://doi.org/10.1080/00131940802649110

Jansen, J., 2009a, 'The curriculum as an institution in higher education', in E.M. Bitzer (ed.), Higher education in South Africa: A scholarly look behind the scenes, pp. 123-154, Sun Media, Stellenbosch.

Jansen, J.D., 2009b, Knowledge in the blood: Confronting race and the apartheid past, Stanford University Press, Palo Alto, CA.

Johnson, L. \& Morris, P., 2010, 'Towards a framework for critical citizenship education', The Curriculum Journal 21(1), 77-96. https://doi.org/10.1080/09585170903560444

Killen, R., 2006, Effective teaching strategies: Lessons from research and practice, 4 th edn., Thomson, Sydney.

Ladson-Billings, G., 1999, 'Preparing teachers for diversity', in L. Darling-Hammond \& G. Sykes (eds.), Teaching as the learning profession, pp. 86-123, Jossey-Bass, San Francisco, CA

Leibowitz, B., 2012, 'Understanding the challenges of the South African higher education landscape', in B. Leibowitz, L. Swartz, V. Bozalek, R. Carolissen \& B. Leibowitz (eds.), Higher education and the public good: Views from the South, B. Leibowitz (eds.), Higher education and the public good: Views from the South,
Trentham Books in collaboration with Sun Media, Stellenbosch, Straffordshire.

Makgoba, M.W., 1997, Mokoko: The Makgoba affair: A reflection on transformation, Vivlia, Florida, Johannesburg.

Mbembe, A., 2015, Decolonizing knowledge and the question of the archive, viewed 06 December 2017, from http://wiser.wits.ac.za/system/files/Achille\%20 Mbembe\%20-\%20Decolonizing\%20Knowledge\%20and\%20the\%20Question\%20 of $\% 20$ the\%20Archive.pdf

Medical and Dental Professions Board of the Health Professions Council of South Africa (HPCSA), 2014, Core Competencies for undergraduate students in clinical associate, dentistry and medical teaching and learning programmes in South Africa, (February), 1-14, viewed 03 June 2015, from http://www.hpcsa.co.za/ uploads/editor/UserFiles/downloads/medical dental/MDB\%20Core\%20 Competencies\%20-\%20ENGLISH\%20-\%2OFINAL\%202014.pdf

Muijs, D. \& Reynolds, D., 2005, Effective teaching: Evidence and practice, Sage, London.

Ogude, N., Nel, H. \& Oosthuizen, M., n.d., The challenges of curriculum responsiveness in South African higher education, Nelson Mandela Metropolitan University, Port Elizabeth. Unpublished internal document. 
Oliver, B., 2013, 'Graduate attributes as a focus for institution-wide curriculum renewal: Innovations and challenges', Higher Education Research \& Development 32(3), 450-463. https://doi.org/10.1080/07294360.2012.682052

Oliver, B., Ferns, S., Whelan, B. \& Lilly, L., 2010, 'Mapping the curriculum for quality enhancement: Refining a tool and processes for the purpose of curriculum renewal', in Proceedings: AuQF2010, Quality in Uncertain Times, Gold Coast, Australia, June $30-J u l y ~ 02$, pp. 80-89.

Pinar, W.F., 2010, 'Currere', in C. Kridel (ed.), Encyclopedia of curriculum studies, pp 177-178, Sage, Los Angeles, CA.

Reid, W.A., 2006, The pursuit of curriculum: Schooling and the public interest, Information Age Publishing, Greenwich, CT.

Smith-Tolken, A., 2011, 'The university curriculum as engaging with external nonacademic communities: A grounded theory inquiry approach', in E.M. Bitzer \& $\mathrm{N}$. Botha (eds.), Curriculum inquiry in South African higher education: Some N. Botha (eds.), Curriculum inquiry in South African higher education: Some
scholarly affirmations and challenges, pp. 349-370, Sun Media, Stellenbosch.

Stefani, L., 2009, 'Planning teaching and learning: Curriculum design and development', in H. Fry, S. Ketteridge \& S. Marshall (eds.), A handbook for teaching and learning in higher education: Enhancing academic practice, 3rd edn., pp. 40-57, Routledge, New York.

Stumpf, R., 2005, A possible programme model for the Nelson Mandela Metropolitan University, workshop of the Interim Management, NMMU, Port Elizabeth.
Terwel, J. \& Walker, D. (eds.), 2004, Curriculum as a shaping force: Towards a principles approach in curriculum theory and practice, Nova Science Publishers, New York.

University A, 2017, Recommendations of the task team for the decolonisation of the university curriculum, unpublished report.

University College Dublin (UCD), 2010, Programme renewal plans, unpublished institutional document, Dublin, Ireland.

University of Adelaide, 2013, Curriculum renewal road map: A compendium of resources to support curriculum review and renewal of coursework programs at the University of Adelaide, Unpublished report, Adelaide, Australia.

University of British Columbia, 2016, First year engineering curriculum renewal project, institutional planning document, Vancouver.

Waters, C.D., Rochester, S.F. \& Macmillan, M.A., 2012, 'Drivers for renewal and reform of contemporary nursing curricula: A blueprint for change', Contemporary Nurse 41(2), 206-215. https://doi.org/10.5172/conu.2012.41.2.206

Werder, C. \& Otis, M.M. (eds.), 2010, Engaging student voices in the study of teaching and learning, Stylus, Sterling, VA.

Yorke, M. (ed.), 2006, Employability in higher education: What it is - what it is not, The Higher Education Academy, London. 